\title{
On the Recent Measurements of Atmospheric Ion Density from the Ground to the Stratosphere
}

\author{
By Yasuhiro Morita, Haruji Ishikawa and Masahiro Kanada \\ The Research Institute of Atmospherics, Nagoya University, Toyokawa, Aichi, Japan \\ (Manuscript received 30 August 1971, in revised form 8 March 1972)
}

\begin{abstract}
Balloon measurements of negative small ion density in the atmosphere from ground to $30 \mathrm{~km}$ have been made in September of 1970. Vertical profiles of negative small ion density have been obtained for daytime and nighttime conditions. The difference between the profiles obtained during daytime and nighttime are discussed. The rapid changes in the ion density are observed in the altitudes below about $3 \mathrm{~km}$. A remarkable decrease in the ion density is observed in the altitudes from 16 to $25 \mathrm{~km}$. During nighttime a second ion density increase is observed in the altitudes of about $30 \mathrm{~km}$. The profiles obtained are compared with those determined from the data of ionization measurements in the atmosphere, assuming ionization equilibrium with small ions. The results obtained from the measurements at a constant level of about $30 \mathrm{~km}$ are also described.
\end{abstract}

\section{Introduction}

The electrical state of the atmosphere is controlled by different conditions of ionization equilibrium existing at different altitudes. For example, the electrical state of lower troposphere is considerably influenced by the suspended submicron particles and it sometimes shows rapid changes near the exchange layer. At stratospheric heights, the ionization is primarily due to cosmic rays and the small ion equilibrium conditions are believed to prevail. Thus balloon measurements of the ion denity can, in principle, lead to a better understanding of the transitional behavior of the electrical state of the atmosphere as we proceed from the ground to the stratosphere.

Many measurements of small ion density in the stratosphere have been made with nearly the same method by different investigators in recent years (Woessner et al., 1958, Kroening, 1960, Paltridge, 1965, 1966 a, Takeuti et al., 1966, Ishikawa et al., 1969, and Morita et al., 1971). However, the results they obtained differ widely from each other and are not always consistent with the simple theory of ionization equiilibirum with small ions. Ishikawa et al. (1969) and Morita and Ishikawa (1969 a) have attempted to interpret the discrepancy between the various observations in terms of the possible influence of atmospheric aerosols on the ion density. Recently, Morita and Ishikawa (1970a) have suggested the possibility of the effect of atmospheric ozone on the temporal variations of small ion density in the stratosphere. In order to investigate the relative importance of the various factors controlling the small ion density in the stratosphere, it thus appears necessary to study the temporal and spatial variations of the ion density in both horizontal and vertical directions. Compared with the vertical measurements of ion density, those seeking to study the temporal and spatial variations at a constant level are, however, relatively few (Paltridge, 1966 b, and Morita and Ishikawa, 1970b). In principle, such measurements at a constant level in the stratosphere could clarify the behavior of aerosols, the influence of the solar ionizing radations, etc. For example, the results of Bragin (1967) suggest that smooth nighttime stratospheric maximum of ion density profile $(10-40 \mathrm{~km})$ is sharply cut off during the daytime and that it consists of several secondary maxima.

In the present paper we discuss some of the results of our recent balloon experiments. Some measurements obtained at a constant level of about $30 \mathrm{~km}$ are also included. 


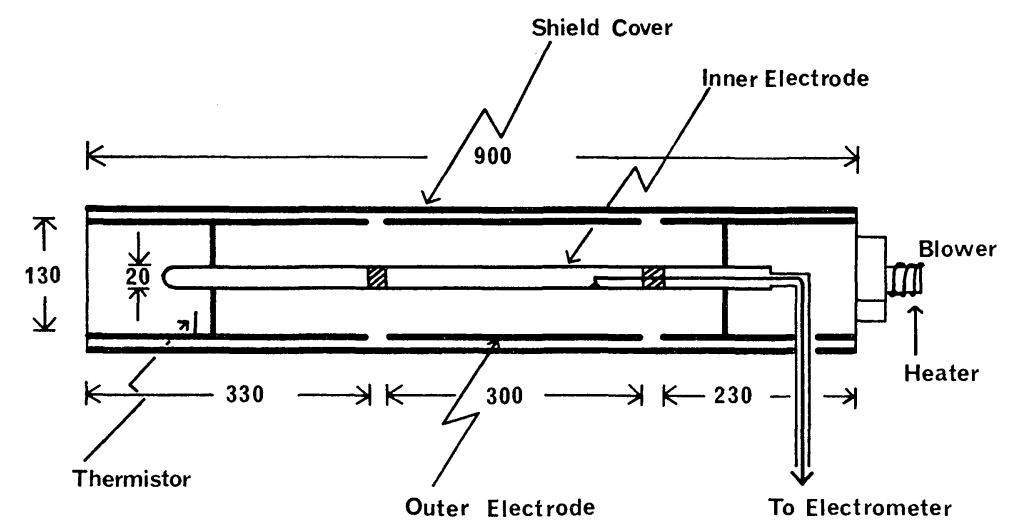

Fig. 1. The schematic diagram of the Gerdien condenser used for nighttime measurements. All the dimensions are in millimeters. For daytime measurements, see Morita et al. (1971).

\section{Experiments}

The basic design of the equipments and the method of measurements used for daytime are the same as those described by Morita et al. (1971). For the nighttime measurements, they are similar to those adopted by Ishikawa et al. (1969), except for some minor changes. As an example, we show in Fig. 1 the schematic diagram of the Gerdien condenser used for the nighttime measurements. For the nighttime measurements, the entire assembly of the equipments was consisted of a Gerdien condenser, temperature sensors, switching barometer, radio sonde, and other accessories. The weight was about $30 \mathrm{~kg}$. The applied voltage to the outer electrode of the condenser was for a typical flow rate of 300 $1 . / \mathrm{min}$. the condenser would be saturated for all ions mobility greater than $1.0 \times 10^{-4} \mathrm{~m}^{2} /$ volt. sec. The ion density which can be measured with the Gerdien condenser depends directly on the rate of air flow which, in its turn, decrease with the battery voltages applied to the blower. In order to calibrate the rate of air flow, the blower current has been checked at an interval of about 2 minutes during the nighttime flight. It may be mentioned here that a number of labortory experiments has been made, prior to the flights, to calibrate the equipments and to ensure the stability of the entire arrangements during the flights. For examples, the characteristics of ion current versus applied voltage to the condenser have been calibrated in the laboratory. The small ion density measured simultaneously and independently by using the two Gerdien

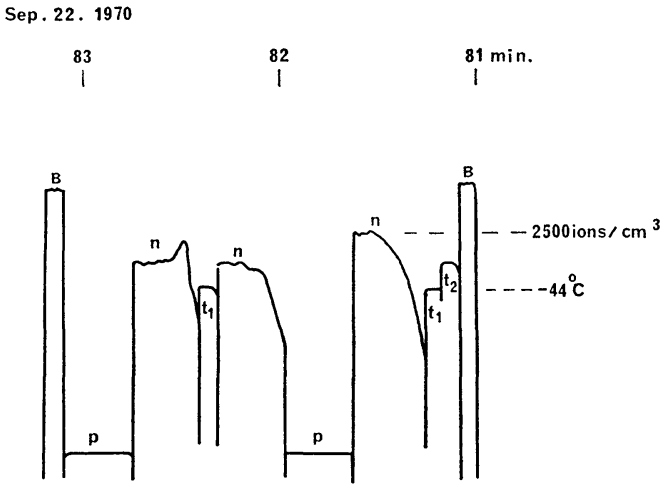

Fig. 2. An example of the actual record, obtained during nighttime flight, showing the values of blower current (B), temperatures of the air both outside $\left(t_{1}\right)$ and inside $\left(t_{2}\right)$ the gondola, ion density $(n)$ and pressure $(p)$. The record corresponds to an altitude range from 24.7 to $25.6 \mathrm{~km}$.

condensers showed a fairly good agreement with each other.

An example of actual record obtained is shown in Fig. 2. The time taken to complete one set of measuremets of all parameters (blower current, temperatures of the air both inside and outside the gondola, ion counts and pressure) was about 2 minutes. The zero level of the condenser was checked automatically every 20 minutes by applying zero voltage to the outer electrode of the condenser. The telemetering frequency used was $1680 \mathrm{MHz}$. The height ranges covered are approximately 25 and $31 \mathrm{~km}$ for daytime and nighttime measurements respectively. 


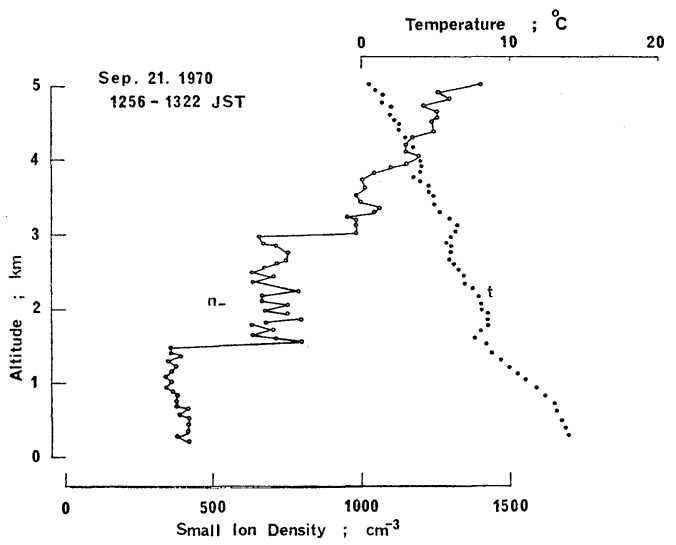

Fig. 3(a). Showing the rapid changes of negative ion density $\left(n_{-}\right)$and air temperature $(t)$ obtained during daytime flight.

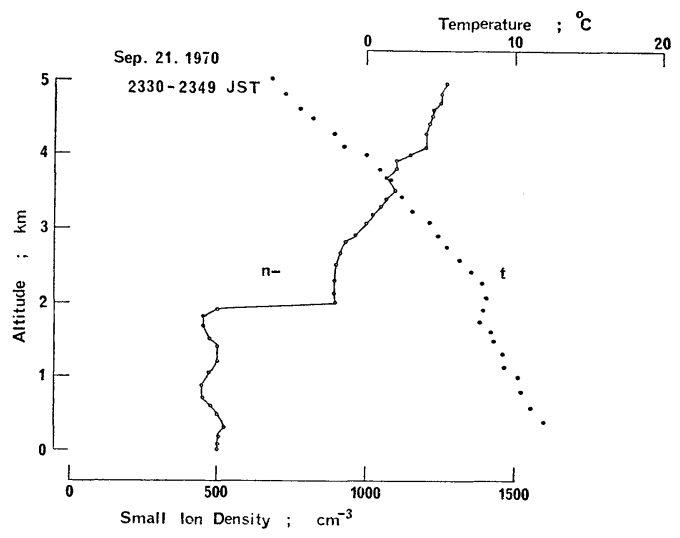

Fig. 3 (b). Same as Fig. 3 (a). Nighttime flight.

\section{Some results and discussion}

3.1. The vertical profiles of small ion density

The electrical state of the atmosphere sometimes shows rapid changes in the lower atmosphere. Measurements showing such rapid changes of the electrical parameters with increasing altitude near the exchange layer have been reported by many workers (Sagalyn and Faucher, 1954, 1956 and others) and the results given by them mostly show the influence of meteorological conditions.

Our results also show sudden changes in the small ion density at certain altitudes as depicted in Figs. 3 (a) and 3 (b). For clarity at lower heights, the full height ranges covered in the experiments are not shown in these figures. In
Fig. 3 (a) which is for the daytime, the ion density is found to change suddenly at two altitudes of about 1.5 and $3 \mathrm{~km}$, which correspond to the temperature inversions, while in the nighttime measurements (Fig. 3 b) a similar change is found to occur at at an altitude of about $2 \mathrm{~km}$. These rapid changes of the ion density meaured could be attributed to the influence of the suspended submicron particles in the lower atmosphere. We have investigated the relevant meterorlogical data with the help of the emagrams obtained from Tateno and Sendai Aerological Observatories. The emagams have suggested that during the periods of balloon flights, possible meteorological conditions conductive to the existence of different air parcels are likely to have existed at these altitudes.

Above these altitudes the ion density shows monotonical increase up to a height of about $14 \mathrm{~km}$ for the daytime and $12 \mathrm{~km}$ for the nighttime. Fig. 4 shows the smoothed up vertical profiles of negative small ion density. For comparison, the positive ion density profile from our previous measurments (Morita et al., 1971) is also shown in the figure. The full line and broken line in the figure show the profiles obtained during nighttime and daytime respectively, while the chain line indicates the positive ion density profile from our previous measurements in daytime. It may be mentioned here that, in the case of daytime measurements, the Gerdien condenser was without blower type and air flowed down through the vertically ascending condenser. The ion density has been obtained by using the downward vertical air flow relative to the condenser. The rate of air flow in the condenser produced by the vertical ascent velocity is a function of Reynolds number. The dependence of Reynolds number on the altitude necessitates the use of a correction factor which, in the present case, has been determined following procedure described by Paltridge (1965) and Morita and Ishikawa (1969 b). The correction factor, with which the ion density has to be multiplied, is in the present case found to be 1.65 for an altitude of $24 \mathrm{~km}$. This value is in good agreement with that obtained by Mühleisen and his co-workers at Weissenau, in West Germany (Mühleisen, private communication, 1970). The daytime profiles shown in Fig. 4 are the corrected profiles.

A few days before our balloon flights at 


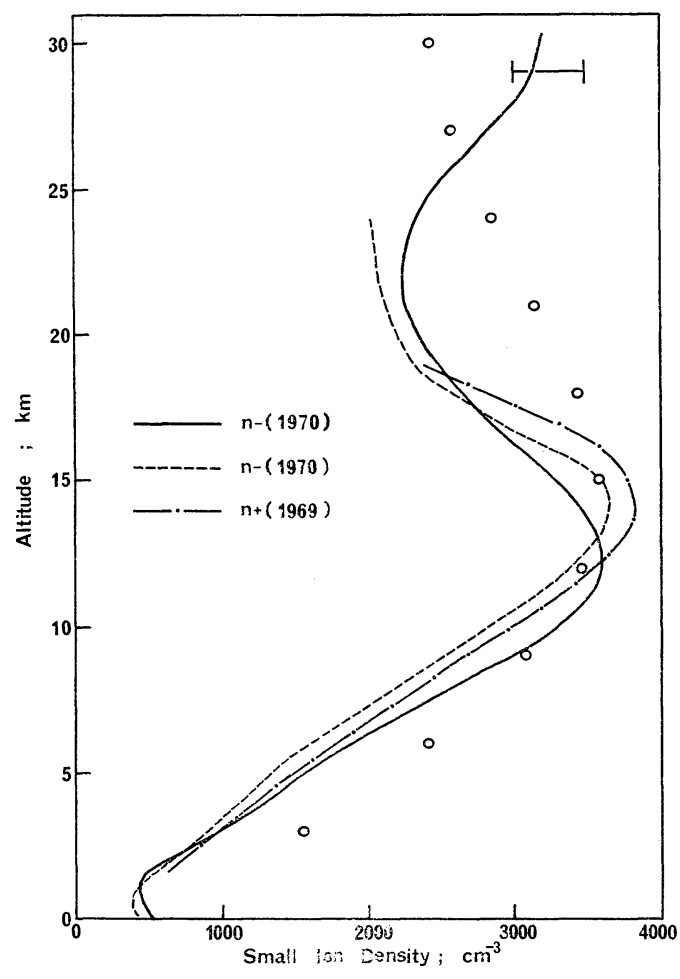

Fig. 4. Comparison of the ion density profiles. The full line and broken line show the negative small ion density obtained during nighttime and daytime respectively, while the chain line indicates the positive small ion density of the previous measurements in daytime. White circles indicate the ion density determined from the ionization measurements. The limits of variations of negative small ion density obtained at a constant level of $29.5 \mathrm{~km}$ are also shown. See text for details.

Haranomachi Balloon Base (geomagnetic latitude $27.7^{\circ} \mathrm{N}$ ), Kawano et al. (Kawano, private communication, 1971) made measurements of the variation of ionization with altitude by means of an air-borne ionization chamber at the same base. Their ionization measurements could be converted into an ion density profile, assuming a reasonable profile for the recombination coefficient between positive and negative ions. Assuming the small-ion theory of Thomson to hold (Stergis et al., 1955), ion densities at various heights have been calculated from the ionization measurements of Kawano et al. and are shown in Fig. 4 as circles depicted at $3 \mathrm{~km}$-intervals. Though the nighttime profile in altitudes between about 9 and $13 \mathrm{~km}$ and the two daytime profiles between about 11 and $15 \mathrm{~km}$ are in agreement with the profile expected from the ionization measurements, discrepancies are quite evident for the nighttime above about $13 \mathrm{~km}$ and below $9 \mathrm{~km}$ and for the daytime above $15 \mathrm{~km}$ and below $11 \mathrm{~km}$. The disagreement, at lower heights, may be attributed to the influence of atmospheric aerosols. This suggestion seem to derive additional support from the calculation of Morita and Ishikawa (1969 a) who, assuming the aerosol content given by Junge et al. (1961), have shown that ion density in the aerosol contaminated air could be different by about $10 \%$ from that in the aerosol-free air at an altitude of about $10 \mathrm{~km}$. The recent calculation made by Shreve (1970) shows that the theoretical ion density increased with altitude, reaching a nearly constant value in the stratosphere. However, the profiles observed show a remarkable decrease above $15 \mathrm{~km}$ for both daytime and nighttime and a minimum of the profile is found at an altitude of about $22 \mathrm{~km}$ in the nighttime. The aerosol content reported by Junge et al., (1961) does not seem adequate to explain the decrease of the ion density in the altitudes between about 16 and $25 \mathrm{~km}$. Recently, Morita and Ishikawa (1970 a) suggested that the variations in the atmospheric ozone density under suitable conditions could cause similar variations in the ion density profile. The suggestion may account, at least partly, for the disagreement at higher altitudes shown in Fig. 4. Another possibility is to invoke the formation of radiolytic and photolytic condensation nuclei. Such formations have been studied in the laboratory (Bricard et al., 1969 and Vohra et al., 1969). The recent work made by Mohnen (1971) indicates the possible formation and existence of metastable or stable condensation embryos in the upper atmosphere. If they were to occur in the stratosphere they would affect the ion density profile. In the case of nighttime measurements, the second increase in the ion density observed above $26 \mathrm{~km}$ cannot be attributed to the influence of stratospheric aerosols. The ion density maxima of two daytime profiles agree with each other in their altitudes, while they are located $2 \mathrm{~km}$ higher than the nighttime peak. This is contrary to the findings of Bragin (1967) who reported that during daytime the lower boundary of the stratospheric ion maximum is situated $5-10 \mathrm{~km}$ closer to the earth's surface 


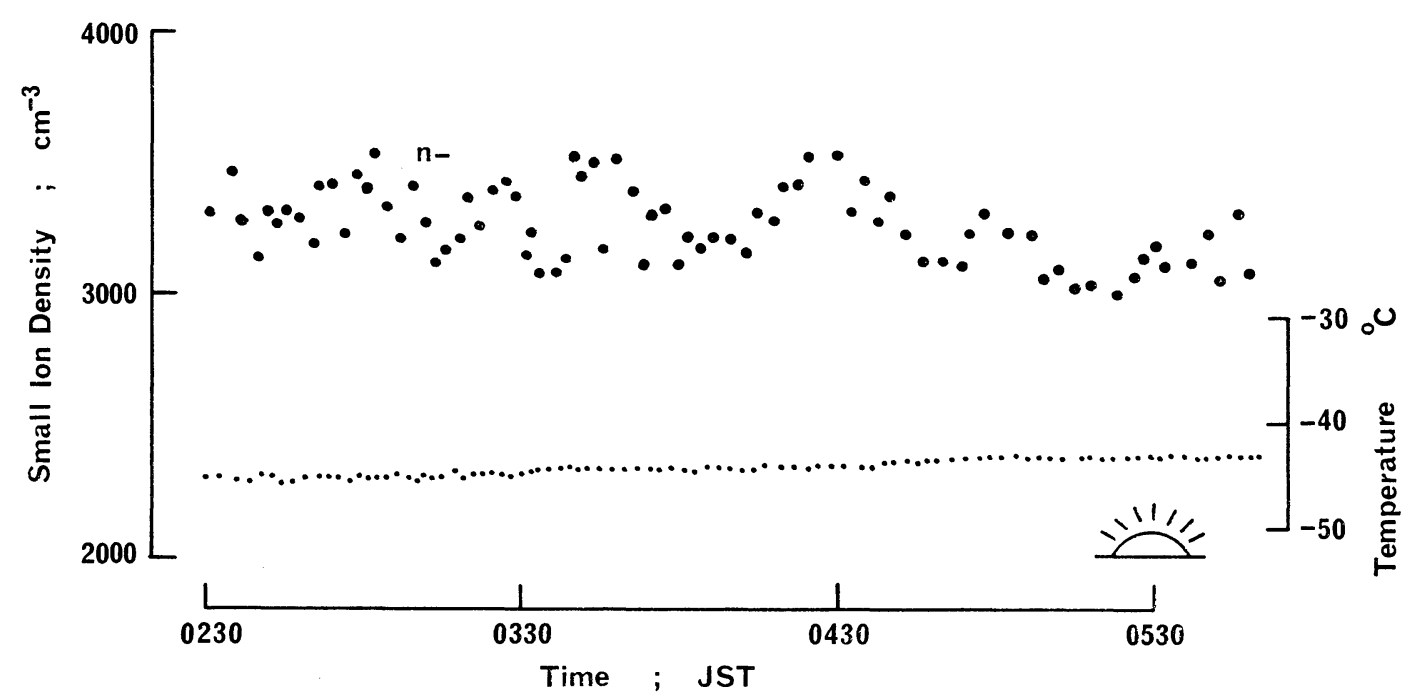

Fig. 5. Showing the variations of negative small ion density (n-) and air temperature $(t)$ at a constant level of $29.5 \mathrm{~km}$.

than nighttime. According to the scheme of Mohnen (1971), the most probable positive small ion is hydronium ion $\mathrm{H}^{+}\left(\mathrm{H}_{2} \mathrm{O}\right)_{n}$, with the most likely value of $\mathrm{n}$ in the stratosphere expected to be 5 or 6 . The degree of hydration depends on temperature and amount of water vapor in the atmosphere. The most important negative ion, at stratospheric heights, is $\mathrm{NO}_{3}^{-}\left(\mathrm{H}_{2} \mathrm{O}\right)_{n}$ and the mechanism of the ion formation relates the atmospheric ozone. It thus would be necessary to investigate a small ion equilibrium which takes into account the nature of small ions and into account the dynamics of the stratospheric circulation in which minor constituents (e.g. ozone, water vapor and others) might play significant role. They would be necessary to account fully for the observed ion density variations with height.

\subsection{The small ion density at a constant level}

The simultaneous records of the negative small ion density and temperature of the air are shown in Fig. 5. The ground sunrise is indicated in the figure. There seems to be a decreasing trend in the time variation, being discernible on the ion density in Fig. 5. In an ideal situation, we would expect a small decrease in the negative ion density following the stratospheric sunrise because of the photodetachment of electrons, especially in the higher regions. It is, however, doubtful if the photodetachment plays any significant role at $30 \mathrm{~km}$ (Cole and Pierce, 1965). Also the Thomson theory predicts a small decrease in the densities of both the positive and negative ions caused by the increase in the recombination coefficient when the temperature increases. However, the temperature variation in the stratosphere is very small as shown in Fig. 5. Thus, the predicted decrease in the ion density should be small. Recently, the results showing the tendency of the negative ion density decrease following the stratospheric sunrise have been reported by Morita and Ishikawa (1970 b). More recently, Coroniti (Coroniti, private communication, 1971) suggests that the evaporation of water vapor from the surface of the balloon or from the instrumental packege itself could cause the decrease in the ion density and points out that shortly after sunrise the water vapor pressure increased by a factor of a thousand.

Our present results indicate that further and more detailed studies of spatial and temporal variations of the ion density in the stratosphere are warranted. 


\section{Concluding remarks}

The negative small ion density obtained in the lower region of the atmosphere shows the sudden changes at a certain altitudes and changes correspond to temperature inversions in both daytime and nighttime. The profiles obtained in both daytime and nighttime are found to agree fairly well with each other except that the two daytime ion density maxima are $2 \mathrm{~km}$ higher than the nighttime peak and that a second increase in the ion density is observed in the altitudes of about $30 \mathrm{~km}$ during the nighttime. All the profiles observed show a remarkable decrease of the ion density in the altitudes between about 16 and $25 \mathrm{~km}$.

The profiles are compared with those calculated from the data of ionization measurements, assuming ionization equilibrium with small ions. The disagreement between the observed and calculated profiles, in the troposphere, may be attributed to the influence of atmospheric aerosols. At stratospheric heights, however, the disagreement cannot be attributed only to the influence of atmospheric aerosols given by Junge et al. (1961). The results obtained at a constant level of about $30 \mathrm{~km}$ seem to show a decreasing tendency toward the dawn hour. The possible factors controlling the small ion density in the stratosphere are discussed.

\section{Acknowledgments}

We wish to express our sincere thanks to Prof. M. Kawano and his co-workers of Nagoya University for their co-operative balloon measurements of ionization. We are indebted also to Prof. J. Nishimura and his staff of the Research Institute of Space and Aeronautical Science, University of Tokyo, for kinkly providing us with the opportunity to carry out balloon experiments. We also thank Dr. M. Rao of Banaras Hindu University of India for his discussions. Finally, our thanks are due to Matsunaga Science Foundation for their financial support of the present work.

\section{References}

Bragin, Yu. A., 1967: Direct investigations of diurnal variations of charged particle concentration profile below $90 \mathrm{~km}$. Kosmicheski Issledovaniya (USSR), 5, 951-952. In Russian. English translation in: Cosmic Res. (USA), 15, 806-807.
Bricard, J., F. Billard and G. Madelaine, 1969: Formation and properties of radiolytic and photolytic condensation nuclei in atmospheric dust-free air, Planetary Electrodynamics. vol. 1, edited by S. C. Coroniti and J. Hughes, Gordon and Breach, New York, 231-241.

Cole, R.K. and E.T. Pierce, 1965: Electrification in the earth's atmosphere for altitudes between 0 and 100 kilometers. J. Geophys. Res., 70, 27352749.

Ishikawa, H., Y. Morita, M. Takagi and A. Iwata, 1969: Balloon observation of small ion density and electric conductivity in the stratosphere. Proc. Res. Inst. Atmospherics, Nagoya Univ., 16, 143-154.

Junge, C.E., C.W. Changnon and J.E. Manson, 1961: Stratospheric aerosols. J. Meteorol., 18, 81-108.

Kroening, J.L., 1960: Ion-density measurements in the stratosphere. J. Geophys. Res., 65, 145-151.

Mohnen, V.A., 1971: Discussion of the formation of major positive and negative ions up to the $50 \mathrm{~km}$ level. J. Pure and Appl. Geophys. 84, 141-153.

Morita, Y. and H. Ishikawa, 1969a: Influence of atmospheric aerosol on the ion density profile up to $30 \mathrm{~km}$ altitude. Proc. Res. Inst. Atmospherics, Nagoya Univ., 16, 43-52.

and H. Ishikawa, $1969 \mathrm{~b}$ Estimation of rate of airflow streaming through a Gerdien condenser in the upper atmosphere from a simulation experiment. Proc. Res. Inst. Atmospherics, Nagoya Univ., 16, 191-196.

and H. Ishikawa, $1971 \mathrm{a}$ : On the possible role of ozone affecting the atmospheric electricity in the stratosphere. J. Atmos. Terr. Phys., 32, 1495-1499.

and H. Ishikawa, 1970b: Measurements of smal! ion density in the stratosphere by level-flight balloon. J. Geomag. Geoelect., 22, 381-382.

H. Ishikawa and M. Kanada, 1971: The vertical profiles of the small ion density and electric conductivity in the atmosphere in $19 \mathrm{~km}$. J. Geophys. Res., 76, 3431-3436.

Paltridge, G.W., 1965: Experimental measurements of the small ion density and electrical conductivity of the stratosphere. J. Geophys. Res., 70, 27512761.

1966a: Stratospheric small-ion density measurements from a high altitude jet aircraft. $J$. Geophys. Res., 71, 1945-1952.

$1966 \mathrm{~b}$ : Time variation in small ion density at 32 kilometers altitude. J. Geophys. Res., 71, 2169-2170.

Sagalyn, R.C. and G.A. Faucher, 1954: Aircraft investigation of the large ion content and conductivity of the atmosphere and their relation to meteorological factors. J. Atmos. Terr. Phys., 5, 253-272. 
time variations of charged nuclei and electrical conductivity of the atmosphere. Quart. J. Roy. Meteor. Soc., 82, 428-445.

Shreve, E.L., 1970: Theoretical derivation of atmospheric ion concentrations, conductivity, space charge density, electric field and generation rate from 0 to $60 \mathrm{~km}$. J. Atmos. Sci., 27, 1186-1194.

Stergis, C.G., S.C. Coroniti, A. Nazarek, D.E. Kotes, D.W. Seymour and J.V. Werme, 1955: Conductivity measurements in the stratosphere. J. Atmos. Terr. Phys., 6, 233-242.

Takeuti, T., H. Ishikawa and A. Iwata, 1966: Preli- minary balloon measurement of negative small ion density. J. Geomag. Geoelect., 18, 493-494.

Vohra, K.G., M.C. Subbaramu, and K.N. Vasudevan, 1969: Role of natural ionization in the formation of condensation nuclei in the atmospheric air. Planetary Electrodynamics, vol. 1, edited by S.C. Coroniti and J. Hughes, Gordon and Breach, New York, 127-135.

Woessner, R.H., W.E. Cobb and R. Gunn 1958: Simultaneous measurements of the postive and negative light-ion conductivities to 26 kilometers. J. Geophys. Res., 63, 171-180.

\title{
地上より成層圈に至る大気イオン密度の最近の測定結果
}

\author{
森田恭弘・石川晴治・金田昌広 \\ 名古屋大学空電研究所
}

1970 年 9 月気球による負イオン密度の測定を行なった。これにより地表より高度約 $30 \mathrm{~km}$ に至るまでの昼間お よび夜間における負イオン密度の高度分布，ならびに夜間約 $30 \mathrm{~km}$ の高度での時間変化を測定することができた。 昼間，夜間とも高度約 $3 \mathrm{~km}$ 以下の下層大気中にイオン密度の明瞭な不連続分布が見いだされた，それらはいずれも 気温の逆転と対応していた，昼夜の高度分布の比較から次のことが明らかになった．通常高度 $12-15 \mathrm{~km}$ 附近に見ら れるイオン密度の最大の高度に関しては冝間は夜間の場合よりも $2 \mathrm{~km}$ 高くあらわれた. 高度約 $26-30 \mathrm{~km}$ で夜間イ オン密度が高度と共に增加してゆくことが測定された。これらの点を除けば昼間および夜間のイオン密度の高度分布 はたがいにほぼ一致していた。 また昼夜とも高度約 16-25 km 附近でイオン密度の著しい減少が見いだされた。

高層大気中で小イオン平衡の成立を仮定し, 電離の気球測定値を用いて算出したイオン密度の高度分布との比較か らは，高度 10-12 km までにおおお々 Junge など (1961) が報告した程度のエーロゾル量の存在が考えられた。成 層圈内のイオン密度の分布についてはこのエーロゾル量だけでは現在のところ説明がつかない．高度約 $30 \mathrm{~km}$ にお ける水平浮遊の際に得られたイオン密度は比較的小さい不規則な時間変化を示したが全体としては日出時に向って減 少してゆく傾向がみとめられた。 